\title{
THE SURVEY OF NORTH BALI PRIMARY SCHOOL STUDENTS' ATTITUDE TOWARD EFL
}

\author{
K. Tia Dwi Pradipta ${ }^{1}$, L.P. Artini ${ }^{2}$ \\ ${ }^{12}$ English Language Education, Post Graduate Program, Universitas Pendidikan Ganesha, Singaraja \\ e-mail: Mtyapradipta@gmail.com, putu.artini@undiksha.ac.id
}

This study aimed for investigating the primary students attitude toward EFL. The study employed a quantitative design in which the data were collected by means of a survey method. The context of the study was in one of primary schools in North Bali. The survey questionnaire was developed based on Wutz and Wedwick (2005) which shows the aspects of attitude. It can was found out that the primary students' demonstrate moderate attitude toward EFL. They were neither notably motivated nor unmotivated in learning English as a Foreign Language at school. This needs further studies to explore factors that could improve the quality of EFL classes in primary schools

\section{Keywords: attitude, EFL, primary school}

\section{INTRODUCTION}

Globalization has united every country in the world and also hit all aspects of human life (Wienda, Markamah, Mahfud, 2014). According to Tirtaraharja and Sulo (2005), there are 4 aspects that become the main target in globalization such as Science and Technology, economics, environment and education. Education is a process experienced by every individual throughout life either intentional or unintentional in order to develop self-ability to face various aspects of life (Rianti, 2012). In terms of its relation to globalization, the educational paradigm has begun to shift towards modern education. In this globalization era, people are demanded to have many skills, and education is expected to prepare students to master those skills in order they are success in their life (Zubaidah, 2016). Furthermore, education becomes very important to guarantee the students to have learning skills, innovations and skills to use technology (Murti, 2013). To support the education in Indonesia, the government has changed the previous curriculum (2006 Curriculum or School Based Curriculum) into curriculum 2013 (Permanasari, 2014). The revision of curriculum has been done to respond or follow the globalization requirements. So the revision of curriculum is expected to give big contributions for the education in Indonesia. Besides that, 21st Century has been marked as the age of the globalization which is characterized as fundamental chance of economy, jobs and businesses; as well as the requirements (Wijaya, Sudjimat, \& Nyoto, 2016). This age requires a qualified individual to survive and compete in global society (Murti, 2013). Thus, Indonesian's government has responded to the requirements throughout strengthening the education; the revision of curriculum is one of actions taken (Harosid, 2017; Melissa, 2017). It is suggested to insert some compulsory elements of the revised 2013 curriculum. There are four basic elements need to be inserted namely; Penguatan Pendidikan Karakter (Strengthening of Character Education), integration of literacy, integration of HOTS (High Order Thinking Skill), and $4 \mathrm{C}$ (Creative, Critical thinking, Communicative, and Collaborative).

According to BSNP (National Education Standards Agency) in 2010, there are 4 things that become notes in relation to the paradigm in Indonesia. First, human education in its entirety, in this case education in Indonesia aims to create an independent person and ready to contribute to his country in order to create a better life. Second, lifelong learning centered on learners, meaning lifelong learning is no age limit and can be implemented anywhere in accordance with the needs of the learners themselves. Third, education for all, one of the rights possessed by all Indonesians is the right to education. In this case, education should be felt by all parties and the government has anticipated by organizing various education such as, formal, informal and non-formal education where according to UU no.20 year 2003, formal education is a structured and tiered education path consisting on basic education, secondary education, and higher education. Furthermore, nonformal education is a non- 
formal education line outside of formal education that can be implemented in a structured and tiered manner. And the last of informal education is the path of family and environmental education. The implementation of formal, informal and non-formal education is a manifestation of the implementation of the concept of Ki Hadjar Dewantara namely Tri Pusat Pendidikan. Tri Pusat Pendidikan is three parts which become center of education that include: 1) Education in the family, education in schools, and education in the community. Education in the family is a learning process that occurs which is a limited organization, and has a minimum size, especially those who initially held a bond, 2) education in schools is a structured and tiered educational path consisting of primary education, secondary education , and higher education. Schools have a purpose to guide, direct and educate so that the institution requires the presence of certain age groups in teacher-led classrooms for the study of the multilevel curriculum; 3 ) the community environment is another environment after the family has much influence on student learning outcomes. The environment teaches them many things, especially the ability to interact with others (honing interpersonal intelligence). The community environment affects the learning outcomes of children through the process of interaction with peers and the game (Nugroho, 2011; Kurniawan, 2015). Fourth, education for sustainable development, in this case education must meet the needs of existing generations and prepare future generations in line with the changing dynamic era and sustainable.

Paradigm submitted by BSNP is in line with the existing paradigm in the world in which according to CISCO (2008), there is a big difference between basic knowledge and knowledge applied in the current era. In basic knowledge, the knowledge taught is English (oral), reading in English, writing by using grammar and spelling studies in English, mathematics, natural sciences, economics, art, geography, history and other foreign languages. This is very different from the knowledge or skills needed in the real world such as critical thinking skills and problem solving, oral and written communication, cooperation, diversity, IT applications, leadership, creativity and innovation, lifelong learning, professionalism and ethics. In this case, it can be said that there is little connection between what is learned and what is applied in society so that the human resources created do not control what actually happens in the real world.

In order to be able to achieve the 4 points submitted by BSNP and the suitability in the latest paradigm in the world, real effort is needed and one of them is by applying 4 pillars of education of UNESCO (UNESCO, 1996) namely "learning to know", "learning to do", "learning to be" learning to live together ". Learning to know has the meaning that humans need to master science and the process of mastery of science is a process that never ends. In this case, as human beings we need to master the basic sciences as a form of preparation for what happens in the real world. Learning to know more is defined as learning to learn where as a human learning process occurs throughout life and the purpose of learning is to meet the purpose of life in the real world. Second, learning to do has the meaning that in learning, as human beings we must be able to have the competencies - the competencies that exist in the real world, such as the ability to think critically and work together. In this case, learning to do more defined as a shift from skill to competence so that required a good adaptation process to the surrounding social environment. Third, learning to be is the application of learning where human beings in a learning process must be able to achieve the full human in the human sense must be good in terms of attitude and can use the knowledge obtained well for the sake of enriching themselves. It can be concluded that in the application of learning to be is using the approach of humanistic or "humanizing human". Finally, learning to live together where as a human being can not be separated with his circumstances as a social being so that as human beings must be able to socialize and live side by side with other human beings so that human beings should be able to work in teams, respect other people's opinions and cooperative.

Based on those explanations, learning is one of the keys to make the people survived in this world. Learning leads the people to their own purposes. According to Skinner (2013), learning is a change in behaviour due to punishment and reinforcement. Change in behaviour in learning means change in positive way for example, from know nothing about the knowledge become know the knowledge, from lazy to read the book become read the book diligently, and many more. According to Rogers (1994), learning is facilitated when the student participates completely in the learning process and has control over its nature and 
direction, it is primarily based upon direct confrontation with practical, social, personal or research problems and self-evaluation is the principal method of assessing progress and success in learning process. Based on Rogers' statement, it can be seen that education is the importance thing to determine the quality of human life. We do not know life without education. In Indonesia, the education system was arranged in good planning. However, how far the education implemented in the school according to the curriculum government roles. Now, the government consent in arrange education system to be better in order to compete with another country. According to Sahroji (2017) Indonesia was in 108 rank in the word with the total score 0,603. It's mean that we were in low education quality. Just $44 \%$ the people in Indonesia past from senior high School, and $11 \%$ the students were goal put. In generally, the quality education in Indonesia were under Palestine, Samoa, and Mongolia. In ASEAN, we were in five rang, start from Singapura, Brunei Darussalam, Malaysia, Thailand, Indonesia, Filipina, Vietnam, Cambodia, Laos, and Myanmar. Risani (2016) stated that education as the leading sector has the important thing to answer the globalization development. Indonesia is a part of social word life and automatically be a member or global competition, such as in politic, economic, culture, and also education. Based on that situation, this is the time for Indonesia to start our performance to be better, especially in Education system. According to UNESCO (2000) about Human Development Index stated that Indonesia Index Development was in low quality. From 174 country in the word Indonesia was on 102 rank in (1996), on 99 rank in (1997), on 105 in (1998), and on 109 in (1999). Education is the root of the country building. In the early of 2015 year was the beginning of the ASEAN Economic Community. Ready or not, Indonesia should be able to compete in preparing a high quality in education.

To receive a quality education is every child's right that must be provided by the government in order to build a better nation. Leeuwen (2016) argues that "education from the earliest school years should be directed to the all-round development of the human personality, spiritual, moral, social, cultural and economic progress of the community. In line with it, the national education system mentions that all children in Indonesia must get quality education equally, which includes development of spiritual, talent and other achievements.

As the primer need, education was the important agenda in our country. Education play the important role in a country development. There were many education problem found, such as the low quality of school building, teacher quality, teacher welfare, students achievement, high education cost, curriculum problem, and others. Indonesian Government tried to present a big change in Education. The government tried to get a good solution in order to give a good service for many aspects. Especially in curriculum problem, the government tried to revise the education system to be better. High technology development play important thing in education quality. The curriculum has change from curriculum 1975 in to curriculum 1984, and then the government change again into curriculum 1994. A new curriculum has born in 2004 in the form of School-Based Curriculum. The change of curriculum in order to revise the education concept, the role and the implementation in order to minimize a bad phenomenon that has be done. According to Mendikbud, the change of curriculum was to revise in continually. The change of curriculum if it was not relevant with the students needs according to globalization development and consent to the purpose of curriculum change was to get the high education quality. In this case the government tried to take the stake holder in education sector, such as administrator, principle, teachers , students, and also the society. At the first the curriculum change tried out in the center town, at the end all of the schools get the occasion to apply a new curriculum. Based on SBC document of English course for junior high school (KTSP, 2006), it is stated that English as an international language plays an important role in students' development either in intellectual, social, or emotional domains. In this case, students are expected to understand any references of English either in written or in spoken which is implemented in four skills of language such as listening, speaking, reading, and writing as well as the other language component. In accordance to this, an English course directed in developing those skills in order to have a graduate of junior high school who are able to communicate in English in certain level of literature.

According to Wells (1987) in KTSP (2006) level of literature consists of per formative, functional, informational, and epistemic. In per formative, people are able to listen, speak, Jurnal Pendidikan Bahasa Inggris Indonesia | 46 
read, and white with the used of symbols. In functional, people are able to use a language to fulfill their needs in their daily life. In informational, people are able to access the level of their achievement in language, while in epistemic people are able to express their knowledge into the goal of language.

Actually, an English course in junior high school is aimed at having the students master the functional level of literature that is students are able to communicate both written and spoken to face the problems in their daily life. To meet the above exception, English course in junior high school is directed to: 1) Develop communicate competence in English both in verbal and nonverbal English to achieve the functional level of literacy. Communicative competence includes listening, speaking, reading, and writing. 2) Build awareness toward the importance of English as a foreign language to face the competition in the era globalization. 3) Develop an understanding about the interrelationship between language and culture.

To achieve those objectives, the teaching learning process of English is expected to have students to attain the following competencies. 1) Discourse competence, that is the capability to understand English both oral and written which is implemented in four language skills, such as listening, speaking, reading, and writing to achieve the functional level of literacy. 2) Comprehend the short functional and monologue text as well as an essy in form of procedure, descriptive, recount, narrative, and report. The gradation of teaching material can be seen in the use of vocabularies, grammar, and steps of rhetoric. 3) Proponent competence involved linguistic competence, sociolinguistic, competence, discourse competence, and strategic competence. Firstly, linguistic competence knows how to use the grammar, syntax, and vocabulary of a language. Secondly, sociolinguistic competence knows how to use and respond to language appropriately, given the setting, the topic, and the relationship among the people communicating. Thirdly, discourse competence knows how to interpret the larger context and how to construct longer stretches of language so that the parts make up a coherent whole. Finally, strategies competence knows how to recognize and repair communication breakdowns, how to work around gaps in one's knowledge of the language, and how to learn more about the language and in the context.

In 2013 the government decided to try out the new designed curriculum, the Curriculum 2013. Thousands of schools, ranging from Elementary ( SD), Juniors High School (SMP) and Senior High School (SMA) have participated in this try out. In Curriculum 2013 implementation all of school activity should based on curriculum 2013. The teachers should be understand in implementing Curriculum 2013 to prepare the gold generation in 2045 . The Gold generation which high competition in behavior, science, and skills as stated in Permendikbud No. 54,2013 it was about Standard of Competency. Permendikbud no. 64 about Standar Isi pendidikan Dasar dan Menengah, permendikbud no. 65, 2013 about Standar Process Pendidikan Dasar dan Menengah. Permendikbud no. 66 tahun 2013 about Standar Penilaian dan Pendidikan.

The process of learning in Curriculum 2013 based on study concept that was learning is students process potency development and character building as the result of synergy between school education, family education and the society. That process give the study opportunity to develop their spiritual, social, science and skills which they need in social life in the form of behavior, science and skill. Here the teacher should arranged the teaching strategy from the simply to the complex, from the concrete to the abstract. The basic experience studying in Curriculum 2013 are observation, asking, collecting information's, association and communicating, as stated in Permendikbud no, 104, 2014 as revised of Permendikbud no. 81 A,2013. In teaching learning process, the students should be active while the teacher should be completed by a good lesson plan and media before entering the classroom. The teacher should be understood about what he/ she going to do in the classroom according to the concept of Curriculum 2013. The change of Curriculum make the teacher confused. In early 2013 as the first year of try out Curriculum 2013, the government give the teacher training about the understanding of the new curriculum. There were some purpose of teacher training, they are: 1. The teacher can understand deeply about the concept and characteristic of new curriculum, 2. The teacher are able to applied the new curriculum in the teaching learning process, 3. Have a good skill in planning the learning in some teaching method, such as: problem based learning, discovery learning, inquiry learning 
project, and many other, 4. The teacher are able to design a lesson plant according to Curriculum 2013,5. The teachers are able to interact with the society, 6 . The teacher can integrate any kind of learning source, and many other. As Kelly (2017) stated that, teacher training can help them feel more confidence about any problem and also prepare new teacher for these challenges. Khan, also stated about the benefit of teacher teaching, that the important of teacher training are enabling to prepared a professional teacher to make proper use of instructional facilities, and developing proper attitudes towards teaching. Based on those explanations, it can be seen that the role of the teacher is important in teaching.

According to Sholeh and Heriyawati (2015) Attitude is a part of learners' perception about themselves, other people, culture in which they live, or culture related to what they learn. Attitude is also related to how the learners respond to what happens in their environment.

This study was supported by some previous research. The first previous research which is used in this study is the study from Farzaneh and Nejadansari in 2014 which concern about student's attitude towards using cooperative learning for teaching reading comprehension. This study used sample from Iranian EFL learner. The data was gathered by using questionnaire. The result showed that the student's response were positive about the implementation of cooperative strategies in teaching and learning reading comprehension

Second, Salameh (2017) which conducted a study entitled "Investigating the Effect of Extensive Reading on EFL Learners' Reading Attitudes at Hail University in KSA". The study used 70 samples from undergraduate participants studying English as a foreign language at Hail University in KSA (Kingdom of Saudi Arabia). The data was gathered by using T-Test. The result showed that extensive reading must be implemented to promote best result.

Third, Agustiani (2017) which conducted a study entitled "The Correlation Between Students' Reading Attitude and Their Reading Comprehension Achievement". The study used 170 students for questionnaire. The data were analyzed by using Pearson Product Moment Coefficients Correlation and Regression Analysis. The result showed students' reading attitude only had a very small contribution to their reading comprehension achievement.

A study conducted by Suswati (2008) focuses on the teaching media, the media selection and the students' responses toward the media used in teaching English at TK PlusAlKautsar Malang. The objective of this study was to describe the teaching media used, to know the criteria used to select the media and the students' responses toward the media used in the teaching and learning process. In this study, the descriptive qualitative design was used to find out the data and analyze it as well. The population of this study was one English teacher and her 122 students of Group B at TK PlusAlKautsar Malang. Group B1 was selected randomly as the sample, which consisted of 30 students. This study investigated the English teacher and her students of B1 in TK PlusAlKautsar. The data were obtained by interviewing the teacher and observing the classroom activity. The findings were analyzed based on the related theory and described descriptively. The result of this study indicated that the media used by the teacher was mostly visual media, they were: pictures, posters, flashcards, puppets, dolls, book, blackboard, and real things. She rarely used audio media; she used a tape recorder and cassette just once in a while for variation. She selected the media which were interesting, attractive, familiar with the children, suitable for the lesson, easily got or made, effective, and easy to apply. Unfortunately, the flashcards were not organized systematically so that the teacher got difficulties to apply them. In addition, the students showed positive responses toward the teaching media.

Taiwo (2009) conducted a study to evaluateteachers' perception of the role of media in the Oyo State of Nigeria. A total of 150 secondary school teachers of Oyo State participated in the study: 110 trained and 40 untrained teachersrandomly selected from ten secondary schools at two gender level (70 females and 80 males). Two media roleswere selected for the study: media used to supplement the teacher by enhancing his effectiveness in the classroom and media used to substitute the teacher through instructional media system. The researchers tested threehypotheses. The findings revealed that there were significant differences in the perceptions of teachers abouteach of the two roles of media identified for the study. In addition, there was a significant difference foundbetween the perceptions of trained and untrained teachers. However, the teachers' gender was not significant. 
Al-Harbi (2015) discussed the influence of TV on children's language development. It investigates the notion that children's educational TV programs may result in vocabulary learning. There were two major findings from the study. The first is that educational TV programs for children are an undeniably useful tool. They become a resource and an affordable alternative means of instruction for children from low-income families. They are also useful for the children of immigrant families because, in a sense, they are primary methods of exposing children to the host culture and its language. This kind of linguistic exposure offers at the least the building blocks of not only the intonation of the language but also the passive vocabularies. The second point is that language is a social phenomenon and it is naturally used in social-communicative settings. As such, interaction with the viewing material is crucial for this new learning process to transform the newly acquired linguistic skills from passive to active. Therefore, a great number of the aforementioned studies found importance in parents' participation in their children's viewing habits in order to take that learning into an interactive context. Hence, interactions with others and with the viewing material are crucial for the educational program to be particularly effective.

Rizki (2015) investigated students' perception of the use of film as a media in English as a Foreign Language (EFL) classroom in SMK N 2 Salatiga, one of the vocational high schools in Salatiga, Central Java, Indonesia. There are many kinds of media that are used as tools in English a Foreign Language (EFL) Classroom, one of the media which is used in EFL classroom, is the film. This study involves seventy (68 males and 2 females) participants from two EFL classrooms of Senior High School level. In obtaining the data, a questionnaire is developed. The participants were asked some questions about their perceptions of the use of films after they were taught through a film several times in their EFL classroom. The result shows that films can be used as the media in the EFL classroom in this school and can be accepted by the students. The result also reveals that the students believed that films are helpful and interesting them in learning English as a Foreign Language. This study is important to be studied to find the benefits on the use of film as a media in EFL classroom, it is hoped that the result of this study can be useful for both of teachers who are teaching English as a Foreign Language and also to the students in learning English as a Foreign Language because other teachers would realize whether yes or not they will use film as media in their own teaching situation.

Rahmi (2017) attempted to explore students' perceptions on the use of instructional media in the classroom. More specifically, the study attempts to answer the following primary question; "how do students perceive the impact of teaching media on their learning" and "what types of teaching media are preferable for students". The sample of the study consisted of 43 students in 8th semester of English Language Education, Faculty of Education and Teacher Training, Ar-raniry state Islamic university. The instruments of the study are; a close-ended questionnaire and interview. The statistic used for data analysis of the close-ended questionnaire, the percentage was used to analyze the participants' responses to the questionnaire items. Qualitative analysis was used to interpret the study participants' responses to the interview questions. The results of the study indicated that there were positive perceptions on the use of instructional media in the classroom. The results of this study may also be useful for those who are interested in this field.

Ngure, Begi, Kimani, and Mweru (2017) conducted a study to investigate the types of instructional media in pre-primary school colleges and tutors' utilization of instructional media during training. The study was carried out in public and private pre-primary school teacher training colleges in Nairobi County. Herzberg's two-factor theory was used to guide the study. The study adopted both qualitative and quantitative research approaches. The key study respondents were all pre-primary school college tutors who taught activity area units in the selected colleges, the programme officers and managers of the selected pre-primary school teacher colleges. A questionnaire for the pre-primary school college tutors, an interview schedule for the programme officers and managers of the selected pre-primary school teacher colleges and an observation checklist were used to gather data. The Statistical Package for Social Sciences (SPSS) was used in the analysis of data. The results revealed that a variety of instructional media were available and used in teaching by the college tutors. The study also revealed that private college tutors utilized instructional media more than public college tutors. 
Abdalla and Ali (2017) investigated EFL students' perceptions and attitudes towards digital media use and integration on language learning at the university level, and how that is an important consideration from foreign language teaching perspectives that faculty need to be aware of. The research studyused the questionnaire as a tool fordata collection. It contains (24) statements that directly relateto students' perception and attitudestowards both technology and EFLlearning from a personal point of view. The population sample of this studywas (70) EFL students chosenrandomly amongst students in the English department of the faculty ofeducation at Khartoum University. They were (35) males and (35) females. From the perceptions and attitudes of EFL students towards digital mediaand language learning in this researchpaper, most of their responses werepositive, whether regarding theirown perceptions, skills and personalexperiences with technology orlanguage learning. A great majority of the participants report theirconfidence in using computer and Internet as key elements that all digital media contents are based onalong other portable devices such assmart and Internet-enabled phones. With regard to the of social media such as Facebook, WhatsApp and other English related websites the majority are members of such sites groups that mainly English oriented. Along with that a great percentage believe that use broaden their proficiency levels, knowledge and skills and technology helped them to build confidence using English to communicate whether in the written or spoken form.

Based on those empirical reviews, this study is different because it is measuring the attitude from primary students about EFL.

\section{RESEARCH METHOD}

The design of this study is a cross-sectional survey research which collected the data at one point in time (Creswell, 2014, pp 41-42 as cited by Sari 2017). This study takes place in one of primary schools in North Bali. The researcher used the questionnaire based on Wutz and Wedwick (2005) because this questionnaire shows the aspects of attitude.

To maintain its validity, the researcher used Pearson Product Moment and the reliability of the data were analyzed by using reliability test by measuring Cronbach alpha. This is the table about the reliability measurement from Candiasa (2010).

Table 1. Ratio in Measuring Reliability

\begin{tabular}{ll}
\hline Reliability Coefficient & Qualifications \\
\hline $0.80-1.00$ & Very High \\
$0.60-0.79$ & High \\
$0.40-0.59$ & Average \\
$0.20-0.39$ & Low \\
$0.00-0.19$ & Very Low \\
\hline
\end{tabular}

After the data were valid and reliable enough, the data were then analyzed by using Qualification Level for Each Perception Table by Koyan (2012) in Permata (2017)

Table 2. Qualification Level of Each Perception

\begin{tabular}{llllll}
\hline No & Interval & $\begin{array}{l}\text { Interval } \\
(24 \text { items })\end{array}$ & $\begin{array}{l}\text { Interval } \\
(20 \text { items })\end{array}$ & Categorization & Qualification \\
\hline \multirow{2}{*}{1} & $\mathrm{Mi}+1.5 \mathrm{SDi} \leq \mathrm{M} \leq \mathrm{Mi}+$ & $60 \leq$ & $50 \leq$ & Very High & Very positive \\
& $3.0 \mathrm{SDi}$ & $\leq 72$ & $\leq 60$ & & Positive \\
2 & $\mathrm{Mi}+0.5 \mathrm{SDi} \leq \mathrm{M}<\mathrm{Mi}+$ & $52 \leq$ & $43.34 \leq$ & High & \\
& $1.5 \mathrm{SDi}$ & $<60$ & $<50$ & & Neutral \\
3 & $\mathrm{Mi}-0.5 \mathrm{SDi} \leq \mathrm{M}<\mathrm{Mi}+$ & $44 \leq$ & $36.66 \leq$ & Average &
\end{tabular}




\begin{tabular}{|c|c|c|c|c|c|}
\hline 4 & $\begin{array}{l}\mathrm{Mi}-1.5 \mathrm{SDi} \leq \mathrm{M}<\mathrm{Mi}- \\
0.5 \mathrm{SDi}\end{array}$ & $\begin{array}{l}36 \leq \\
<44\end{array}$ & $\begin{array}{l}30 \leq \\
<36.66\end{array}$ & Low & Negative \\
\hline 5 & $\begin{array}{l}\mathrm{Mi}-3.0 \mathrm{SDi} \leq \dot{\mathrm{X}}<\mathrm{Mi}- \\
1.5 \mathrm{SDi}\end{array}$ & $\begin{array}{l}24 \leq \\
<36\end{array}$ & $\begin{array}{l}20 \leq \\
<30\end{array}$ & Very low & $\begin{array}{l}\text { Very } \\
\text { Negative }\end{array}$ \\
\hline
\end{tabular}

Note :

$$
\begin{array}{lll}
\mathrm{Mi} & =1 / 2 \quad \text { (ideal maximum score }+ \text { ideal minimum score }) \\
\mathrm{SDi} & =1 / 6 \quad \text { (ideal maximum score }- \text { ideal minimum score) }
\end{array}
$$

\section{FINDINGS AND DISCUSSION}

Before the questionnaire is given, the questionnaire must be measured first. questionnaire contains 14 questions and 7 of them are valid. Besides that, the reliability score for the questionnaire is 0.607

As the reliability index is 0.607 , the questionnaire can be assumed as highly reliable because this is between 0.60-0.79

Tabel 3. Reliability Statistics

\begin{tabular}{rrr}
\hline Cronbach's Alpha & N of Items & \\
\hline .607 & & 14 \\
\hline
\end{tabular}

This is the finding from the survey session:

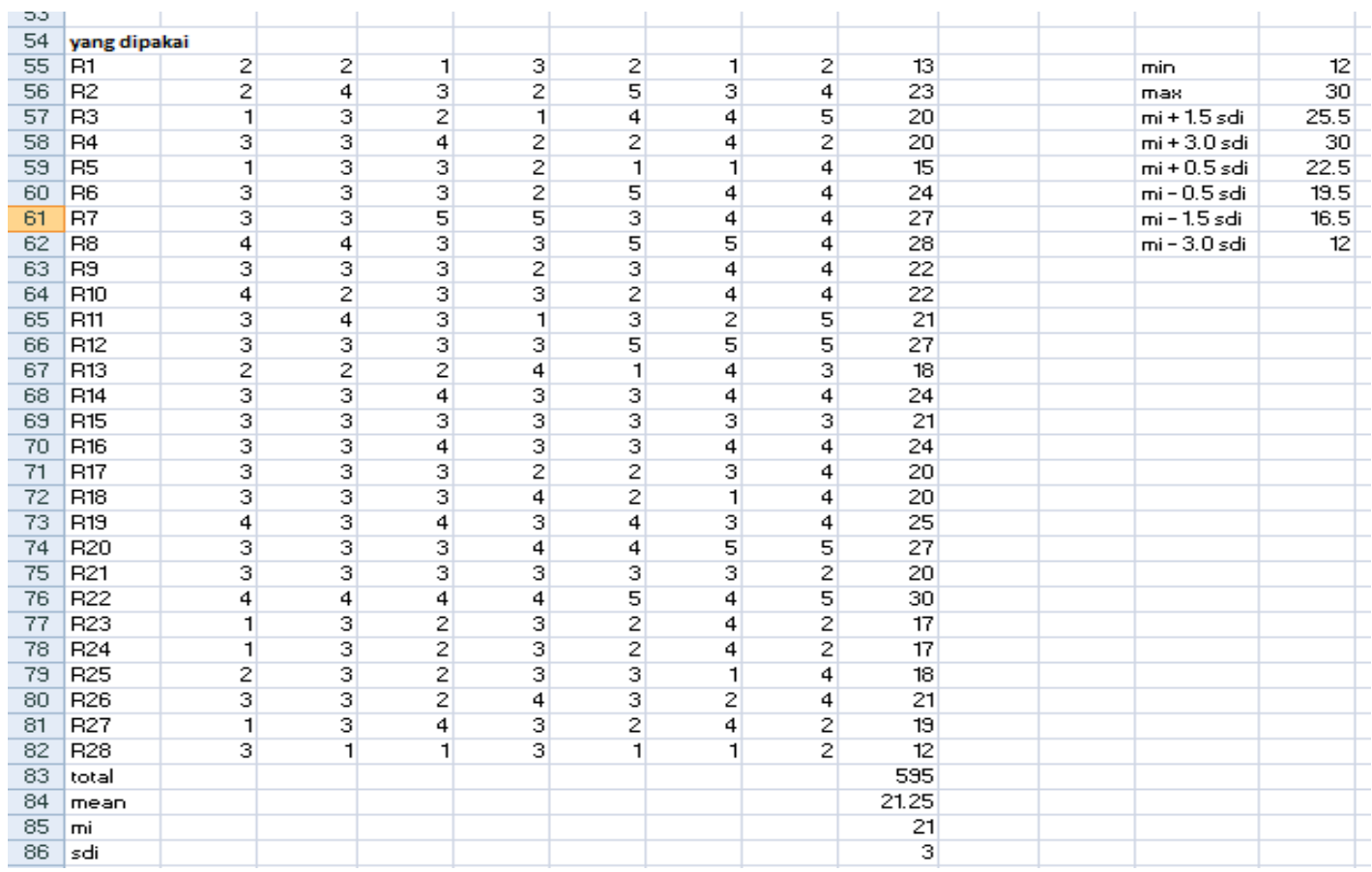

The data in the table revealed that the attitude mean score of the primary school students about English was represented by the figure of 21.25 . This is between $\mathrm{mi}+0.5$ sdi which is $22.5 \mathrm{mi}-0.5$ sdi which is 19.5 , which means that students did not show neither a notably positive nor negative in learning English. This is not surprising because English classes we organized and managed in a similar way as teaching other subjects. Classes run as a routine where students as to sit quietly listening to teachers and do work when they are assigned to.

\section{CONCLUSION}

This study found that primary school students tend to consider English classes as a learning routine as represented by the mean score of 21.25 in their attitude towards English 
subject. This needs further research on the factors that may contribute to a better learning atmospheres that make the children more enthusiastic as well as more positive about learning the foreign language.

\section{REFERENCES}

Agustiani. I. W. (2017). The Correlation Between Students' Reading Attitude and Their Reading Comprehension Achievement. English Community Journal (2017), 1 (2): 7585

Akbari, H., Ghonsooly, B., Ghazanfari, M., Shahriari, H. (2017). Attitude Toward Reading: L1 or L2 or Both. SAGE Open July-September 2017: 1-10 () The Author(s) 2017 DOI: 10.1177/2158244017717303 journals.sagepub.com/home/sgo

Asmari, A.R.A. (2013). Practices and Prospects of Learner Autonomy: Teachers' Perceptions. English Language Teaching; Vol. 6, No. 3; 2013 ISSN 1916-4742 E-ISSN 1916-4750 English Language Teaching; Vol. 10, No. 7; 2017 ISSN 1916-4742 E-ISSN $1916-4750$

Alonazi, S.M. (2017). The Role of Teachers in Promoting Learner Autonomy in Secondary Schools in Saudi Arabia.

BSNP.(2010). Paradigma Pendidikan Nasional Abad XXI. BADAN STANDAR NASIONAL PENDIDIKAN Versi 1.0 - Tahun 2010

CISCO. (2008). 21stCentury Skills: How can you prepare students for the new Global Economy? Charles Fadel Global Lead, Education Cisco Systems, Inc

Creswell. (2012). Educational Research Planning, Conducting and Evaluating Quantitative and Qualitative Research. United States of America: PEARSON

Himadara, I.A, Artini, L.P, Marhaeni, A.A.I.G, (2013). Developing Materials to Provide Language Learning Environment to Support Grade 5 Students 's Literacy Skill in English. e-Journal Program Pascasarjana Universitas Pendidikan Ganesha Program Studi Pendidikan Bahasa Inggris (Volume 1 Tahun 2013)

Kasten, W.C, Wilfong, L.G. (2005). Encouraging independent reading with ambience: The Book Bistro in middle and secondary school classes. 2005 INTERNATIONAL READING ASSOCIATION (pp. 656-664) doi:10.1598/JAAL.48.8.3

Rianti. I. 2012. Landasan Pendidikan Nasional. AT-TA'LIM; Vol. 3, Tahun 2012

Sari, N.K.D.P. (2017). A Survey On Fifth Grade Students and Teachers' reception On The Use of ICT Based Interactive Game in Sukasada District. Ganesha University of Education

Tirtarahardja, Sulo. 2005. Pengantar Pendidikan (Edisi Revisi). Jakarta: PT Asdi Mahasatya

UNESCO. (1996) Learning The Treasure Within. UNESCO Publishing

Wienda, Markamah, Mahfud. (2014). Jurnal Didaktika Dwija Indria (SOLO) Vol 2, No 4 tahun 2014: April

Wuttz, A.J, Wedwick, L. (2005). BOOKMATCH: Scaffolding Book Selection for Independent Reading. 2005 International Reading Association (pp. 16-32) doi:10.1598/RT.59.1.3 